\title{
Detailed bathymetry and magnetic anomaly in the Central Ryukyu Arc, Japan: implications for a westward shift of the volcanic front after approximately $2.1 \mathrm{Ma}$
}

\author{
Taichi Sato , Hirokuni Oda, Osamu Ishizuka and Kohsaku Arai
}

\begin{abstract}
Detailed bathymetry and magnetic anomalies in the southern part of the Central Ryukyu Arc reveal recent volcanic structures in a southwestward extension of the active volcanic front of the Ryukyu Arc. A line of bathymetric highs running subparallel to this recent volcanic front was observed approximately $20 \mathrm{~km}$ to the east. A set of small, sharply defined magnetic anomalies extends southward from this line of bathymetric highs to the islands Kume-jima and Aguni-jima, suggesting the former existence of an ancient volcanic front. The ages of volcanic rocks from these islands indicate that magmatic activity along the ancient volcanic front continued until at least approximately $2.1 \mathrm{Ma}$. The presence of magnetic anomalies between the two volcanic fronts suggests that the volcanic front has moved gradually westward. This shift can be explained by the termination of asthenospheric upwelling and/or the rapid retreat of the Ryukyu Trench after its change in subduction direction.
\end{abstract}

Keywords: Ryukyu Arc; Okinawa Trough; Arc volcanism; Seafloor morphology; Magnetic anomaly

\section{Findings}

Introduction

The Ryukyu Arc extends approximately 1,200 km between the islands of Kyushu and Taiwan, where the Philippine Sea Plate subducts northwestward under the Eurasian Plate. The rate of convergence across the arc increases from $40 \mathrm{~mm} / \mathrm{yr}$ in the northern part of the arc to 67 to $71 \mathrm{~mm} / \mathrm{yr}$ in the southern part (Seno et al. 1993). From east to west, the arc consists of the Ryukyu Trench, the Ryukyu Islands, a volcanic front, and the Okinawa Trough (Figure 1). The Ryukyu Arc is generally divided into northern, central, and southern regions bounded by the Tokara Strait and the Kerama Gap (e.g., Konishi 1965; Kato et al. 1982). The Tokara Islands are on the presentday volcanic front, which extends from Kyushu into the eastern margin of the Okinawa Trough in the Central Ryukyu Arc. Active volcanic islands do not occur to the southwest of Iotori-shima in the Central Ryukyu Arc,

\footnotetext{
* Correspondence: taichi-sato@aist.go.jp

Geological Survey of Japan, AIST, 1-1-1 Higashi, Tsukuba, Ibaraki 305-8567, Japan
}

although some bathymetric highs and associated magnetic anomalies have been reported (Otani et al. 2004).

The Okinawa Trough is generally interpreted as being in the early stage of rifting (e.g., Sibuet et al. 1987, 1995, 1998; Miki 1995; Shinjo et al. 1999; Fournier et al. 2001; Hsu et al. 2001; Fabbri et al. 2004; Lin et al. 2005). We have divided the Okinawa Trough into northern, central, and southern regions corresponding to the divisions of the Ryukyu Arc (Konishi 1965) (Figure 1). Active back-arc rifting accompanied by volcanic ridges and numerous volcanoes has been recognized in the Central Okinawa Trough (e.g., Sibuet et al. 1987; Oshima et al. 1988) but not in the North Okinawa Trough. Geochemical research has suggested that enriched mid-ocean ridge basalt (E-MORB)-type upwelling of the asthenospheric mantle and a subduction component have been involved in the generation of basalt in the Central Okinawa Trough (Shinjo et al. 1999). This implies that the magmatic activity of the volcanic front and back-arc overlap in the Central Okinawa Trough.

However, whether the volcanic front to the southwest of Iotori-shima existed in the past is unknown, and the cause of the possible overlap of the two types of 


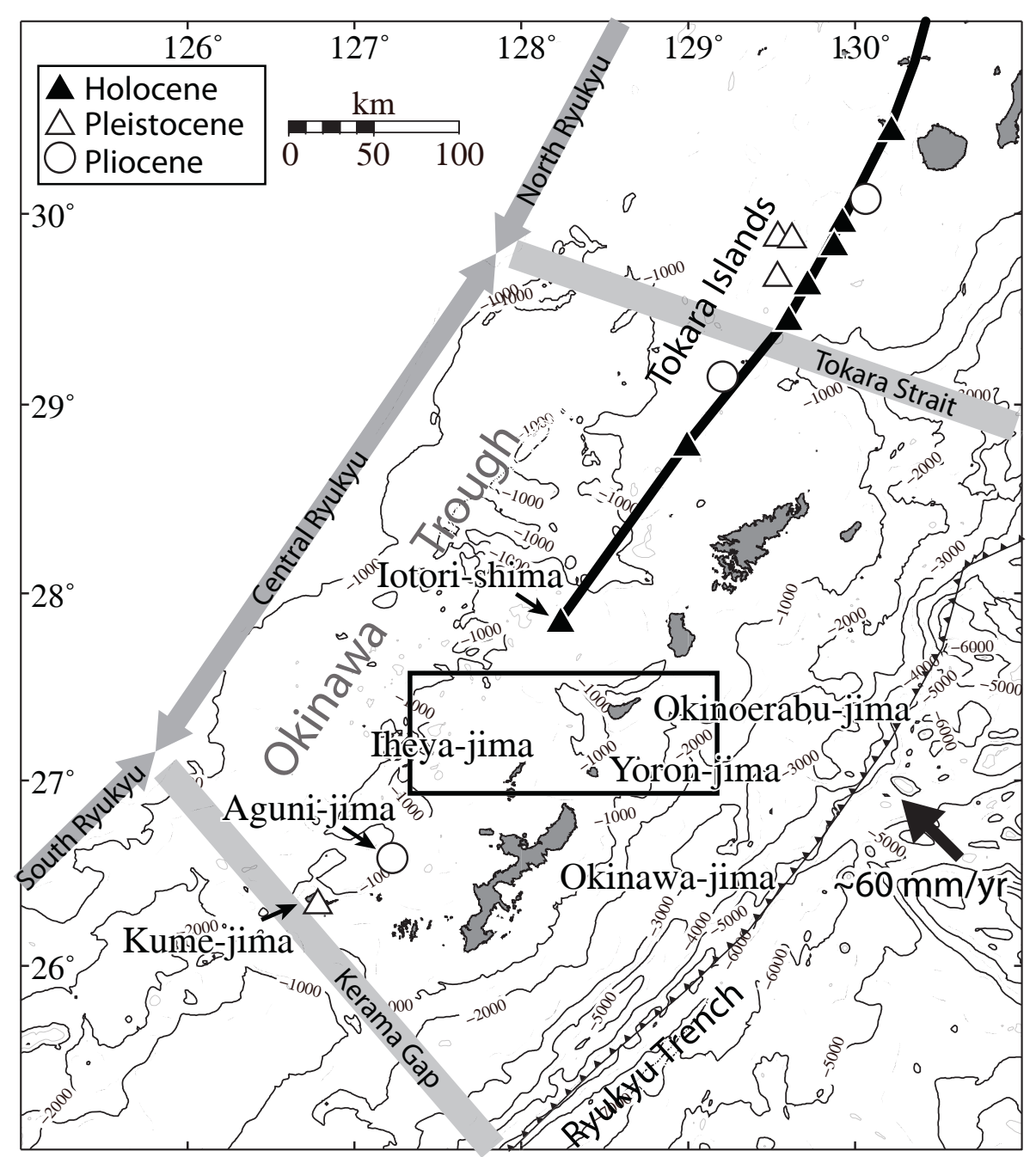

Figure 1 North and Central Ryukyu Arc seafloor bathymetry. Seafloor bathymetry of North and Central Ryukyu Arc showing the present-day volcanic front (thick black line), Holocene volcanoes (open triangles), Pleistocene volcanoes (open circles), and Pliocene volcanoes (solid triangles) (Geological survey of Japan (AIST) 2013). Contour interval is $500 \mathrm{~m}$. Large arrows indicate plate motion direction of the Philippine Sea Plate relative to the Eurasian Plate (Seno et al. 1993). Black rectangle indicates the survey area. Figure was drawn using JTOPO30 (Japan Hydrographic Association, Tokyo, Japan).

magmatic activity in the Central Ryukyu Arc is not clear. Clarifying the temporal and spatial variabilities of magmatic activity in the volcanic front and back-arc region will contribute to the understanding of the early rifting process of this region.

To address these issues, we conducted a detailed geophysical survey by using bathymetry, gravity and magnetics in the Central Ryukyu Arc around the islands of Yoron-jima, Okinoerabu-jima, and Iheya-jima (Figure 2). Such geophysical surveys are known to be useful in delineating submarine volcanic features (e.g., Kim et al. 2013). This survey was performed in 2012 during the Geological Survey of Japan, National Institute of Advanced Industrial Science and Technology (AIST), GH12 cruise of R/V Hakurei.

\section{Geophysical data acquisition and processing}

Bathymetric data were collected with a multi-beam echo sounding system (EM122, Kongsberg Maritime AS, Kongsberg, Norway) composed of 432 beams with an operating frequency of $12 \mathrm{kHz}$. The sound velocity correction used real-time data from the surface water velocity meter and the sound velocity profiles collected by conductivity, temperature, and depth (CTD), expendable CTD (XCTD), and expendable bathythermograph (XBT) observations in the study area. We used HIPS and SIPS software (CARIS, Ltd., Fredericton, Canada) to remove extreme depth variations from the outer edges of the multibeam swaths.

Total magnetic field data were acquired at 1-s intervals with a surface-towed cesium magnetometer (G-882, 


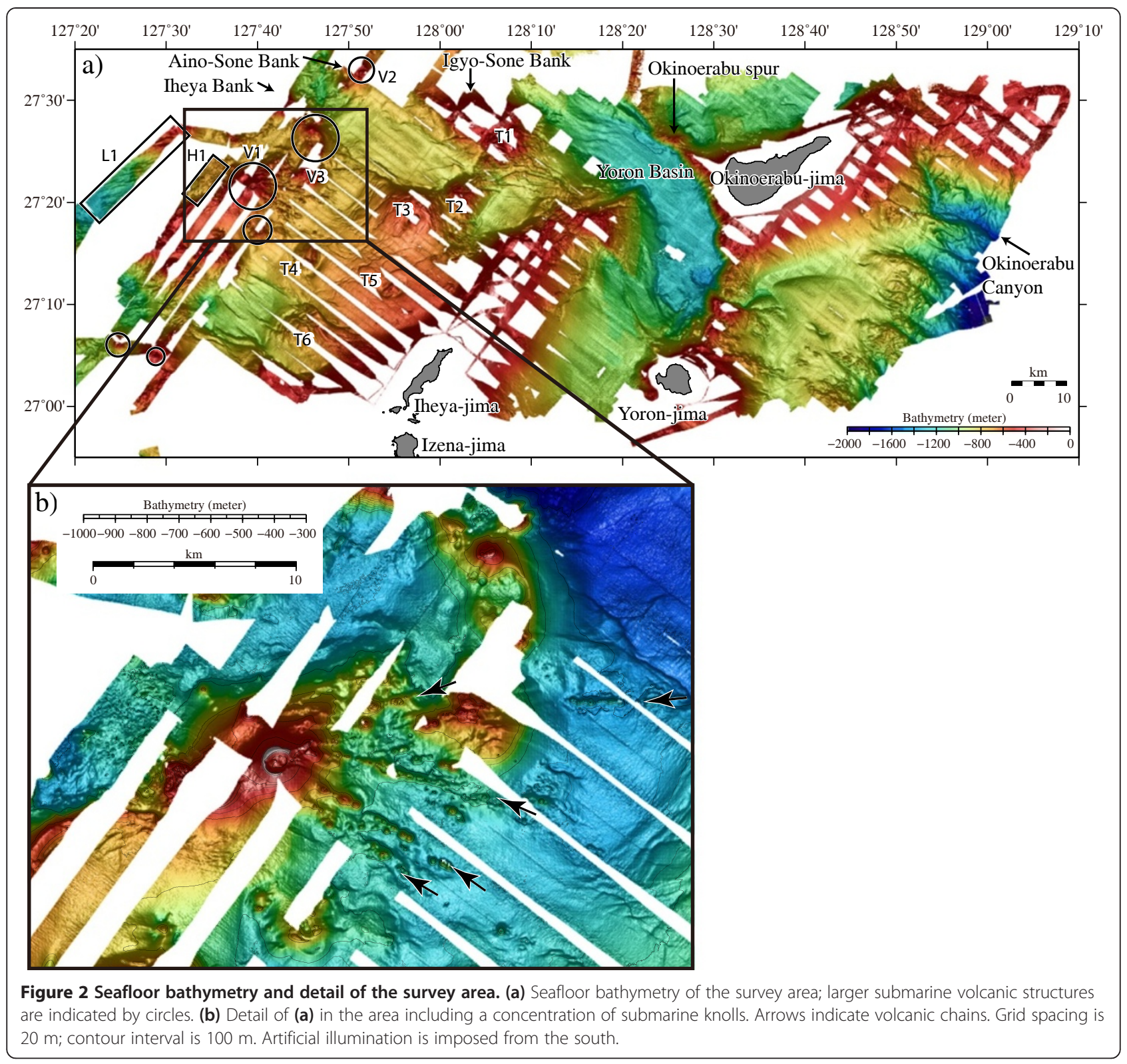

Geometrics, Inc., San Jose, CA, USA). The sensor was towed $240 \mathrm{~m}$ behind the ship to minimize the ship's magnetization effect. Magnetic anomalies were calculated by subtracting the 11th generation International Geomagnetic Reference Field (Finlay et al. 2010) from the observed magnetic field intensity. Magnetic diurnal variation was corrected using data from the Gesashi magnetic observatory on Okinawa-jima operated by the Geospatial Information Authority of Japan. Crossover error assumed to be mainly caused by the ship's magnetization was minimized by using the software package x2sys of Generic Mapping Tools (GMT) (Wessel 2010; Bullard and Mason 1961). These corrections reduced the standard deviation at crossover points from 12.2 to $5.1 \mathrm{nT}$. Finally, the reduced-to-pole magnetic anomaly was calculated using Mirone software (Luis 2007). The direction of seafloor magnetization was assumed to be the same as that of the geocentric axial dipole field of the study area.

\section{Results}

\section{Bathymetry}

The survey area is in the middle of the Central Ryukyu Arc around the islands of Yoron-jima, Okinoerabu-jima, and Iheya-jima (Figure 2a). The water depth in the survey area is between 500 and $1,200 \mathrm{~m}$. Yoron-jima and Okinoerabu-jima are non-volcanic islands connected by a NE-SW-trending shallow ridge. Several well-developed submarine canyons, such as Okinoerabu Canyon, cut into the upper fore-arc slope east of the islands of the 
Ryukyu Arc. A basin approximately 1,200 m deep, the Yoron Basin, lies west of Okinoerabu-jima. Northeast of Iheya-jima, a NE-SW-trending ridge 400 to $500 \mathrm{~m}$ high rises at a depth of approximately $1,000 \mathrm{~m}$. About $60 \mathrm{~km}$ north of Iheya-jima, the Igyo-Sone Bank lies at a depth of approximately $500 \mathrm{~m}$. Southwest of this bank, several isolated knolls rise approximately 100 to $300 \mathrm{~m}$ above the seafloor at depths of 500 to $600 \mathrm{~m}$. These features are numbered T1 to T6 in Figure 2a.

In the westernmost part of the survey area, several submarine knolls as large as $8 \mathrm{~km}$ in diameter are observed. Because some of them have craters, they are interpreted as submarine volcanoes. The largest one with a crater, at $27^{\circ} 22^{\prime} \mathrm{N}, 127^{\circ} 39^{\prime} \mathrm{E}$, is approximately $500 \mathrm{~m}$ high (Figure 2b). Just west of these volcanoes, hummocky terrain (H1 in Figure 2a) similar to those often found in the axial areas of mid-ocean ridges (e.g., Lawson et al. 1996) is observed. Many small conical structures less than $1 \mathrm{~km}$ in diameter are also observed in this area (Figure 2b). Some of them have summit craters, and others are aligned in chains with orientations between ENE-WSW and SE-NW (arrows in Figure 2b); all are interpreted as volcanic origin. Farther to the west, ENE-WSW-trending lineaments (L1 in Figure 2a) are interpreted as being caused by normal faults associated with rifting in the Okinawa Trough.

\section{Magnetics}

Reduced-to-pole magnetic anomalies vary between -110 and $640 \mathrm{nT}$ (Figure 3a). East of the Ryukyu Arc, the anomaly varies between -20 and $60 \mathrm{nT}$ and is relatively featureless. However, five well-defined positive magnetic anomalies are observed in a line extending southwest from the southern end of Igyo-Sone Bank (M1 to M5 in Figure 3a). The largest of these, reaching $640 \mathrm{nT}$ (M1), corresponds to the southern part of the Igyo-Sone Bank. Some of these positive anomalies are associated with knolls. A weak positive anomaly is observed over the small submarine volcanoes and volcanic chains west of anomaly M4 (Figures $2 \mathrm{~b}$ and $3 \mathrm{a}$ ). Positive anomalies as large as $120 \mathrm{nT}$ are observed over the two largest volcanic knolls (V1 and V2). The area of hummocky terrain (H1 in Figure $3 \mathrm{a})$ is associated with a negative anomaly.

\section{Discussion}

\section{Recent volcanic front}

The volcanic front in the Central Ryukyu Arc has been delineated by previous studies (e.g., Sibuet et al. 1998). Geochemical data from submarine volcanoes and several volcanic chains have been documented in the northern part of this segment (Yokose et al. 2010). However, magmatic activities in the southern part are less well known, despite the presence of magnetic anomalies associated with topographic highs (Geological Survey of Japan (AIST)
(2002); Otani et al. 2004) and the discovery of pumice approximately $300 \mathrm{~m}$ deep in a bank at $27^{\circ} 17^{\prime} \mathrm{N}, 127^{\circ} 29^{\prime} \mathrm{E}$ (Otani et al. 2004). Many submarine volcanic structures observed in the western part of the survey area are generally aligned in a NE-SW direction (Figure 2a) in the southwestward extension of the present-day volcanic front at the Tokara Islands (Figure 1). This suggests that the volcanic front once extended into the southern part of the Central Ryukyu Arc. Therefore, we recognized this line of volcanoes as a recently active part of the volcanic front. The two largest submarine volcanic knolls (V1 and V2 in Figure 2) have clear positive magnetic anomalies larger than $100 \mathrm{nT}$ (Figure 3a), implying that they were active volcanoes during a normal-polarity chron or short-term normal events during a reversed-polarity chron. In addition, a positive magnetic anomaly was observed over the chains of small volcanic knolls (arrows in Figure 2b), suggesting the presence of igneous rocks beneath the seafloor, which may correspond to magmatic bodies of ancient volcanoes (Figures $2 \mathrm{~b}$ and $3 \mathrm{a}$ ). These small volcanic knolls belong to the $\mathrm{V}$-series, and the orientations of these chains appear to be related to previous tectonic extensions (Fournier et al. 2001).

\section{Ancient volcanic front}

We observed a line of positive magnetic anomalies oriented NE-SW in the middle of the survey area (M1 to M5 in Figure 3a), which is subparallel to the present and recent volcanic fronts and approximately $20 \mathrm{~km}$ east of the recent volcanic front. Bathymetric and seismic surveys during the GH12 cruises (Sato et al. 2013) showed that these anomalies coincide with knolls (M1 to M3 and M5) and a buried basement high (M4) that display no evident volcanic structures, suggesting sediment cover and weathering. This chain of magnetic anomalies is a part of a larger magnetic feature observed in the southern half of the Central Ryukyu Arc (Geological Survey of Japan (AIST) (2002)) (Figure 3b). Therefore, we interpreted the chain to be a part of an ancient volcanic front.

Kume-jima and Aguni-jima islands to the south of this feature are associated with notable positive magnetic anomalies (Figure 3b). Kume-jima has two recognized volcanic formations, the Aradake Formation of Miocene age and the Uegusukudake Formation of Pliocene age (Nakagawa and Murakami 1975). Andesites from the Aradake Formation show fission-track ages of $15.1 \pm$ 2.6 Ma and 12.8 $\pm 2.1 \mathrm{Ma}$ (Daishi et al. 1987). Volcanic rocks in the Uegusukudake Formation show K-Ar dates of $2.76 \pm 0.48 \mathrm{Ma}$ from picrite basalt in the lowest part (Ito and Shiraki 1999), 2.24 $\pm 0.10 \mathrm{Ma}$ from andesite in the upper part (Miki 1995), and 2.13 $\pm 0.19 \mathrm{Ma}$ from basaltic andesite lava in the middle part (Kitagawa and Shinjo 2001). A Pliocene high-Mg andesite from O-jima, just east of Kume-jima, shows a K-Ar date of $6.08 \pm 0.46 \mathrm{Ma}$ (Shinjo 


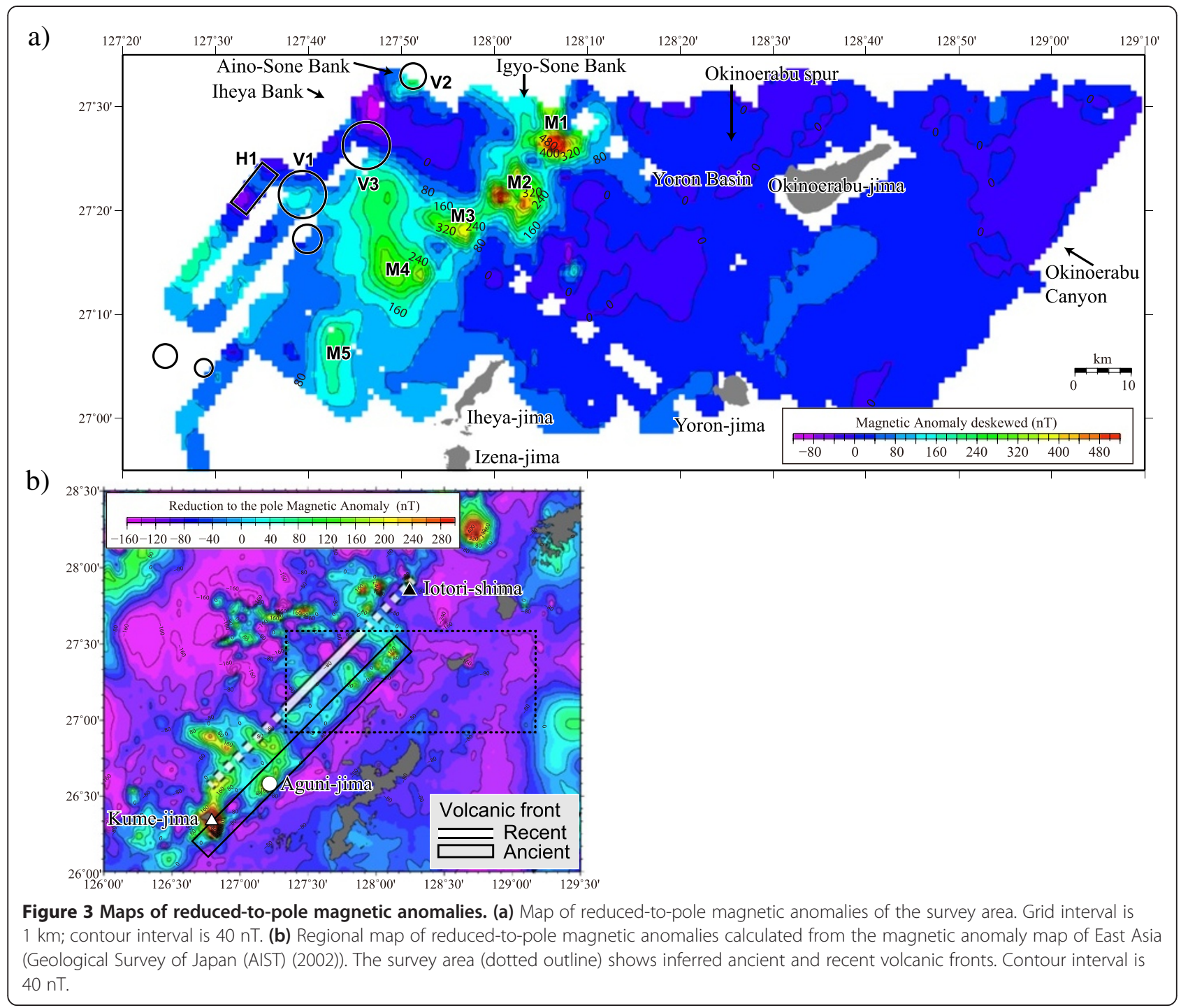

et al. 1991). On Aguni-jima, the age of the volcanic Aguni Formation is between the late Miocene and early Pliocene (Kizaki 1986). Dacite of the Aguni Formation shows a fission-track date of 6.24 $\pm 0.46 \mathrm{Ma}$ (Daishi et al. 1987).

These dated rocks suggest that magmatic activity in the southern half of the Central Ryukyu Arc continued until around approximately $2.1 \mathrm{Ma}$, and high- $\mathrm{Mg}$ rocks were produced as late as approximately 2.3 Ma. Although we have no radiometric ages for the rocks associated with the magnetic anomalies M1-M5 (Figure 3a), the association of the anomalies with dated volcanic rocks in the southern half of the Central Ryukyu Arc (Figure 3b) suggests that magmatic activity persisted in the survey area into early Pleistocene time.

\section{Shift of volcanic front toward the back-arc region}

No notable magnetic anomalies or topographic features indicative of volcanic structures are found east of the ancient volcanic front (Figure 3b). This finding, together with the presence of small magnetic anomalies between the recent and ancient volcanic fronts, suggests that the volcanic front has moved gradually to the west (Figure $3 \mathrm{a}, \mathrm{b})$.

According to the slab model of Hayes et al. (2012), the slab depths are 80 to $90 \mathrm{~km}$ beneath both the active volcanic front of the Ryukyu Arc around the Tokara Islands in the North Ryukyu Arc and the recent volcanic front identified in this study (Figure 4). These slab depths are also consistent with the established concept that the position of the volcanic front is governed by dehydration of the subducting plate (e.g., Tatsumi 1986; Kogiso et al. 2009). The current slab depth beneath the ancient volcanic front is approximately $70 \mathrm{~km}$, which is shallower than that beneath the recent and present volcanic fronts (Figure 4). Assuming that the slab depth was deeper when the ancient volcanic front was active, the subsequent westward shift of the volcanic front would 


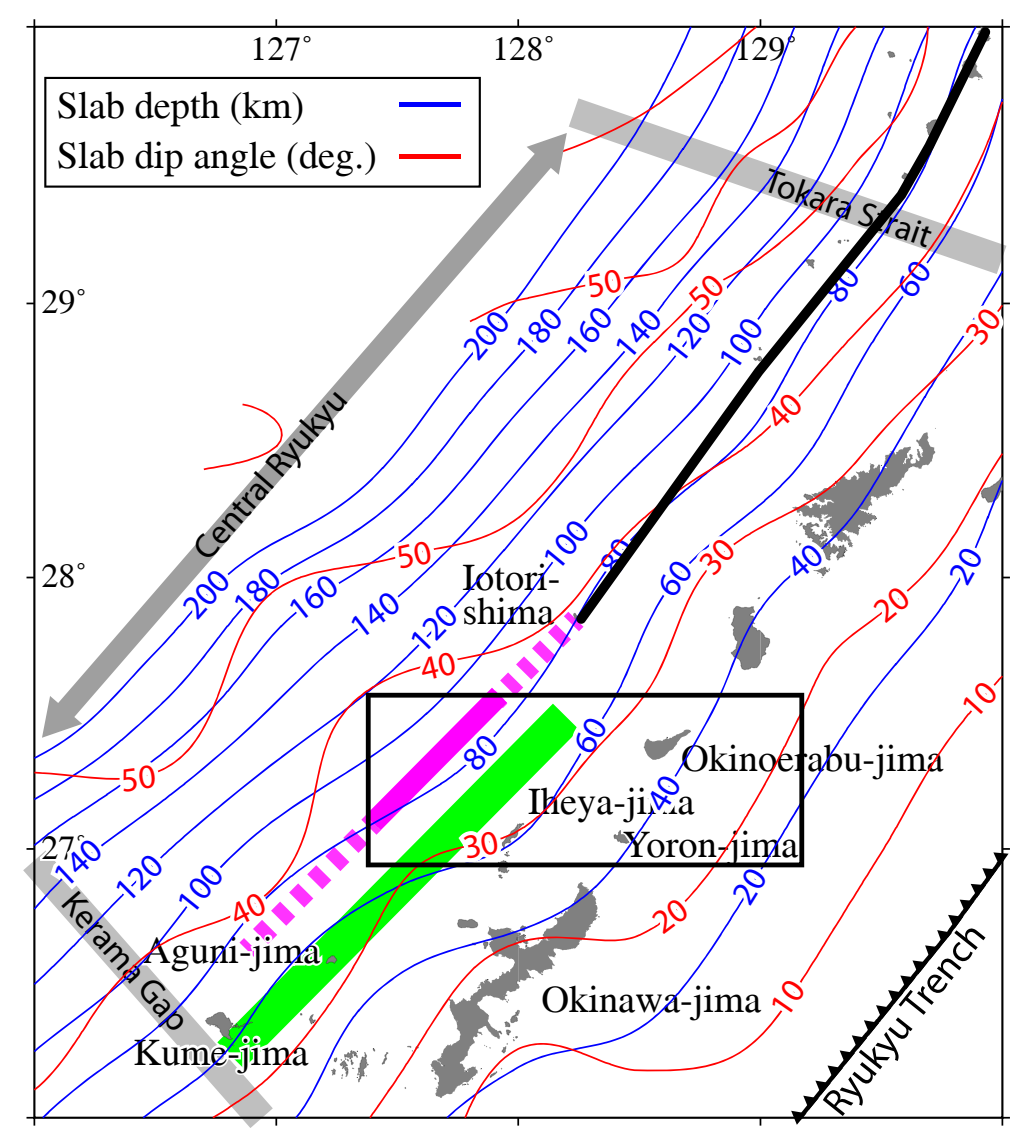

Figure 4 Slab geometries beneath the Central Ryukyu Arc derived from Slab1.0 (Hayes et al. 2012). Blue contours indicate slab depth; red contours indicate slab dip angle. The present-day, recent, and ancient volcanic fronts are indicated by thick black, magenta, and green lines, respectively. The survey area is outlined in black.

have been accompanied by shallowing of the slab beneath it (Figure 5). We propose two possible explanations for this change in the subduction geometry: termination of asthenospheric upwelling beneath the southern part of the Central Ryukyu Arc (Figure 5a) and rapid trench retreat due to a change in the subduction direction of the Philippine Sea Plate (Figure 5b).

The first hypothesis is based on the model proposed by Shinjo (1999). Relatively primitive basalt and high-Mg andesites of middle to late Miocene age have been found in the Central and South Ryukyu Arc (e.g., Shinjo 1999). For example, adakitic high-Mg andesites from the Central Ryukyu Arc show the clear geochemical signature of a slab-derived component from the slab melt (Shinjo 1999). Although many adakites were produced during the subduction of young, hot oceanic crust of less than $25 \mathrm{Ma}$ (Defant and Drummond 1990), the subducting Philippine Sea Plate beneath the Central Ryukyu Arc consists of relatively old oceanic crust of approximately 54 to approximately $26 \mathrm{Ma}$ (Deschamps and Lallemand 2002). Therefore, asthenospheric upwelling is postulated to have produced the adakitic high-Mg andesite (Shinjo
1999). The ages of the picrite basalt (Ito and Shiraki 1999) suggest that asthenospheric upwelling continued until no later than approximately $2.3 \mathrm{Ma}$ (a1 in Figure 5a). Asthenospheric upwelling can affect the depth and dip angle of the slab by changing the thermal state or mantle flow beneath the volcanic front. Currently, the slab dip angle differs between the North and Central Ryukyu Arc (e.g., Shiono et al. 1980; Christova 2004). According to the slab model of Hayes et al. (2012), there is a distinct difference (approximately 5 to $10^{\circ}$ ) in the slab dip angle beneath the volcanic front in the Tokara Islands in North Ryukyu Arc and that beneath the submarine volcanoes in the Central Ryukyu Arc identified in this study (Figure 4). This difference in the slab dip is attributed to a difference in shear resistance to the subduction (e.g., Shiono et al. 1980; Kao and Chen 1991; Christova 2004); when resistance is greater, a slab is subjected to more compressional stress and has a shallower dip. Alternatively, the slab dip angle is attributed to the degree of pressure force generated by mantle flow (e.g., Heuret and Lallemand 2005); weakening the mantle flow pushing on the upper plate side of the 
a) Model 1: Termination of asthenospheric upwelling

a1) Before $\sim 2 \mathrm{Ma}$

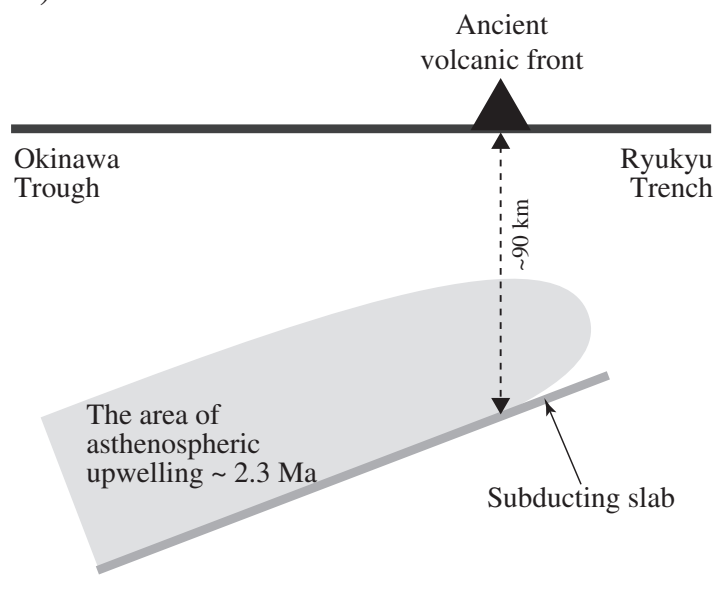

a2) 2 Ma to Present

Westward shift of volcanic front after $2.1 \mathrm{Ma}$

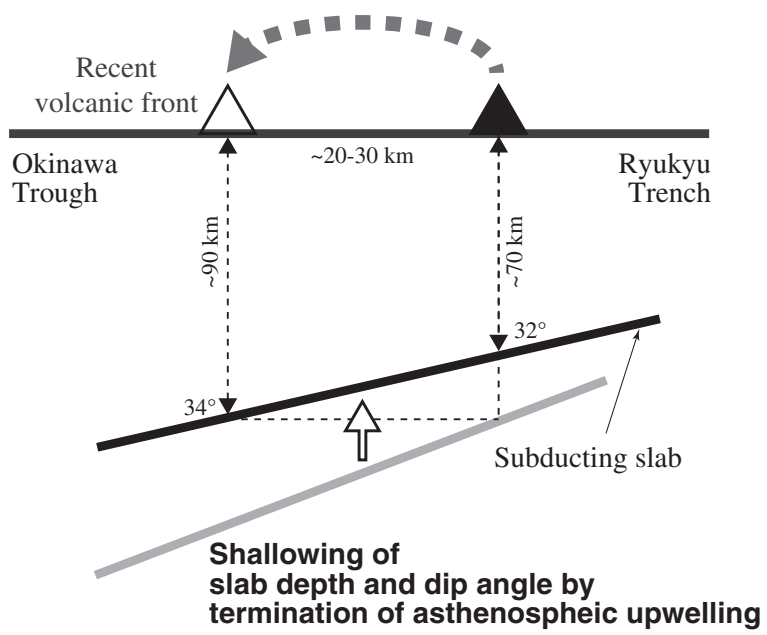

b) Model 2: Rapid trench retreat



b2) 2 Ma to Present

Westward shift of volcanic front after 2.1 Ma

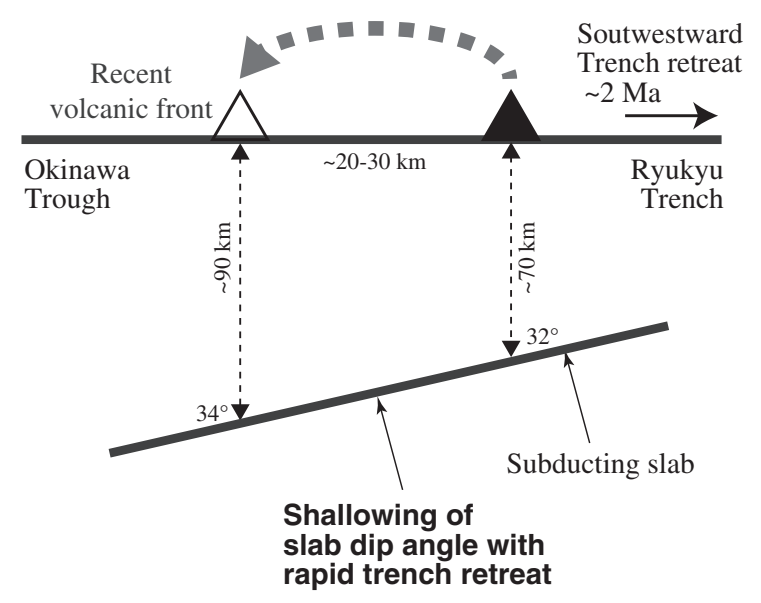

Figure 5 Schematic models for the westward shift of the volcanic front in the Central Ryukyu Arc. Shallowing of slab depth and dip angle caused by (a) termination of asthenospheric upwelling and (b) rapid trench retreat due to the change in subduction direction of the Philippine Sea Plate at approximately $2 \mathrm{Ma}$. The scales of vertical, horizontal, and slab dip angles are arbitrary.

slab creates a shallower slab dip angle. Based on the previous geochemical studies, we suggest that the contribution of asthenospheric upwelling to volcanism in the ancient arc ended at approximately $2.3 \mathrm{Ma}$. This change may have decreased the mantle temperature to result in an increase in the resistance to subduction; alternatively, it may have weakened the asthenospheric mantle flow to result in a decrease in pressure. Both mechanisms can lead to shallowing of the slab depth and dip angle (a2 in Figure 5a). The second hypothesis is inferred from the rapid trench retreat of the Ryukyu Arc proposed by Kamata and Kodama (1999).
The change in the subduction direction of the Philippine Sea Plate from N-NW to NW occurred at approximately $2 \mathrm{Ma}$, and oblique subduction has replaced the arc-normal subduction at the Central Ryukyu Arc, resulting in a more rapid southeastward retreat of the Ryukyu Trench (Kamata and Kodama 1999). Assuming that the initial slab dip angle was steeper than its current position (b1 in Figure $5 b$ ), and if the slab was anchored in the mantle and its dip shallowed with the trench retreat, westward migration of the volcanic front is likely (b2 in Figure 5b). To clarify the timing of the shift of the volcanic front and to assess our proposed 
models, integrated geological and geophysical surveys from the ancient to the recent volcanic front, including deep drilling, are necessary.

\section{Conclusions}

A geophysical survey in the southern part of the Central Ryukyu Arc revealed detailed bathymetry and magnetic anomalies, which were then interpreted in combination with regional magnetic data. The following conclusions are drawn:

(1) A recently active volcanic front of the Ryukyu Arc occurs along the southwestward extension of the present-day volcanic front, according to conical topographic structures that are interpreted as submarine volcanoes.

(2) Well-defined magnetic anomalies associated with basement topographic highs suggest the presence of an ancient volcanic front that is subparallel to and approximately $20 \mathrm{~km}$ east of the recent volcanic front. Being as Kume-jima and Aguni-jima would be a part of the ancient volcanic front, the ages of the volcanic activity at these islands indicate that the ancient volcanic front may have been active until approximately $2.1 \mathrm{Ma}$.

(3) The geometry and magnetic features of these two volcanic fronts suggest a gradual westward shift of the southern part of the Central Ryukyu arc's volcanic front in Quaternary time. We offer two candidate mechanisms for this shift. The first is shallowing of the slab depth and dip angle induced by the termination of asthenospheric upwelling beneath the southern part of the Central Ryukyu Arc. The second is rapid southeastward retreat of the Ryukyu Trench approximately $2 \mathrm{Ma}$.

\section{Competing interests}

The authors declare that they have no competing interests.

\section{Authors' contributions}

$\mathrm{TS}, \mathrm{HO}$, and $\mathrm{KO}$ conducted the geophysical survey. TS and $\mathrm{HO}$ processed the data. All contributed to discussion, and $\mathrm{TS}, \mathrm{HO}, \mathrm{Ol}$, and $\mathrm{KO}$ wrote the manuscript. All authors read and approved the final manuscript.

\footnotetext{
Acknowledgements

The data used in this study were obtained by the Geological Survey of Japan of National Institute of Advanced Industrial Science and Technology (AIST), conducted as part of the marine geological survey of the region around Okinawa. We thank the captain and crews of R/V Hakurei and the GH12 cruise science party for their help in collecting data and for offering valuable advice.
}

Received: 24 February 2014 Accepted: 30 June 2014 Published: 7 July 2014

\section{References}

Bullard EC, Mason RG (1961) The magnetic field astern of a ship. Deep Sea Res 8:20-27

Christova C (2004) Stress field in the Ryukyu-Kyushu Wadati-Benioff zone by inversion of earthquake focal mechanisms. Tectonophysics 384:175-189
Daishi M, Hayashi M, Kato Y (1987) Radio-metric ages of some Cenozoic volcanic rocks from Ryukyu Islands. J Jpn Assoc Miner Petrol Econ Geol 82:370-381 (in Japanese with English abstract)

Defant MJ, Drummond MS (1990) Derivation of some modern arc magmas by melting of young subducted lithosphere. Nature 347:662-665

Deschamps A, Lallemand S (2002) The West Philippine Basin: an Eocene to early Oligocene back arc basin opened between two opposed subduction zones. J Geophys Res 107:2322

Fabbri O, Monie P, Fournier M (2004) Transtensional deformation at the junction between the Okinawa trough back-arc basin and the SW Japan island arc. In: Grocott J, McCaffrey KJW, Taylor G, Tikoff B (ed) Vertical coupling and decoupling in the lithosphere. Geological Society Publishing House, Bath, pp 297-312

Finlay CC, Maus S, Beggan CD, Bondar TN, Chambodut A, Chernova TA, Chulliat A, Golovkov VP, Hamilton B, Hamoudi M, Holme R, Hulot G, Kuang W, Langlais B, Lesur V, Lowes FJ, Luhr H, Macmillan S, Mandea M, McLean S, Manoj C, Menvielle M, Michaelis I, Olsen N, Rauberg J, Rother M, Sabaka TJ, Tangborn A, Toffner-Clausen L, Thebault E (2010) International Geomagnetic Reference Field: the eleventh generation. Geophys J Int 183:1216-1230

Fournier M, Fabbri O, Angelier J, Cadet JP (2001) Regional seismicity and on-land deformation in the Ryukyu arc: Implications for the kinematics of opening of the Okinawa Trough. J Geophys Res 106:13751-13768

Geological Survey of Japan (AIST), Coordinating Committee for Coastal and Offshore Geoscience Programmes in East and Southeast Asia (CCOP) (2002) Magnetic Anomaly Map of East Asia 1:4,000,000, 2nd edn. CD-ROM Version, p-3. Geological Survey of Japan (AIST), Tukuba

Geological Survey of Japan (AIST) (2013) Volcanoes of Japan, 3rd edn. 1:2,000,000. Geological Map of Japan. No 11. Geological Survey of Japan (AIST), Tukuba

Hayes GP, Wald DJ, Johnson RL (2012) Slab1.0: A three-dimensional model of global subduction zone geometries. J Geophys Res 117, B01302

Heuret A, Lallemand S (2005) Plate motions, slab dynamics and back-arc deformation. Phys Earth Planet Inter 149(1-2):31-51

Hsu SK, Sibuet JC, Shyu CT (2001) Magnetic inversion in the East China Sea and Okinawa Trough: tectonic implications. Tectonophysics 333:111-122

Ito J, Shiraki K (1999) Picrite basalts from the Pliocene Uegusukudake Formation in Kume-jima, Ryukyu islands. J Geol Soc Jpn 105:810-813 (in Japanese with English abstract)

Kamata H, Kodama K (1999) Volcanic history and tectonics of the Southwest Japan Arc. Isl Arc 8:393-403

Kao H, Chen WP (1991) Earthquakes along the Ryukyu-Kyushu arc: strain segmentation, lateral compression, and the thermomechanical state of the plate interface. J Geophys Res 96:21443-21485

Kato S, Katsura T, Hirano K (1982) Submarine geology off Okinawa Island. Rep Hydrogr Res 17:31-70 (in Japanese with English abstract)

Kim HJ, Jou HT, Lee GH, Na JH, Kim HS, Jang U, Lee KY, Kim CH, Lee SH, Park CH, Jung SK, Suk BC (2013) Caldera structure of submarine Volcano \#1 on the Tonga Arc at $21^{\circ} 09^{\prime}$ S, southwestern Pacific: Analysis of multichannel seismic profiling. Earth Planets Space 65:893-900

Kitagawa H, Shinjo R (2001) Whole-rock K-Ar age for a basaltic andesite from the Uegusukudake Formation in Kume-jima, Central Ryukyu Arc. Miner Petrol Sci 30:237-240 (in Japanese with English abstract)

Kizaki K (1986) Geology and tectonics of the Ryukyu Islands. Tectonophysics 125:193-207

Kogiso T, Omori S, Maruyama S (2009) Magma genesis beneath Northeast Japan arc: a new perspective on subduction zone magmatism. Gondwana Res 16:446-457

Konishi K (1965) Geotectonic framework of the Ryukyu Islands (Nansei-Shoto). J Geol Soc J.jn 71:437-457 (in Japanese with English abstract)

Lawson K, Searle RC, Pearce JA, Browning P, Kempton PD (1996) Detailed volcanic geology and geochemistry of the MARNOCK area (Mid-Atlantic Ridge north of Kane Transform). In: MacLeod CJ, Taylor PA, Walker CL (ed) Tectonic, magmatic. hydrothermal and biological segmentation of mid-ocean ridges. Blackwell Scientific, Oxford, pp 61-102

Lin JY, Sibuet JC, Hsu SK (2005) Distribution of the East China Sea continental shelf basins and depths of magnetic sources. Earth Planets Space 57:1063-1072

Luis JF (2007) Mirone: a multi-purpose tool for exploring grid data. Comput Geosci 33:31-41

Miki M (1995) Two-phase opening model for the Okinawa Trough inferred from paleomagnetic study of the Ryukyu arc. J Geophys Res 100:8169-8184

Nakagawa H, Murakami M (1975) Geology of Kume-jima, Okinawa Gunto, Ryukyu Island. Inst Geol Paleontol Tohoku Univ Miyagi Jpn Contrib 75:1-16 (in Japanese with English abstract) 
Oshima S, Takanashi M, Kato S, Uchida M, Okazaki I, Kasuga S, Kawashiri C, Kaneko Y, Ogawa M, Kawai K, Seta H, Kato Y (1988) Geological and geophysical survey in the Okinawa trough and the adjoining seas of Nansei Syoto. Rep Hydrogr Res 24:19-43 (in Japanese with English abstract)

Otani Y, Tsuchide M, Shibata A, Kato S, Iwabuchi Y (2004) List of volcanoes and their activities records in the adjacent seas of Japan (3th edition). Rep Hydrogr Oceanogr Res No 40:1-62 (in Japanese with English abstract)

Sato T, Arai K, Matsumoto D (2013) Preliminary result of the GH12 seismic survey. In: Arai K (ed) Marine geological and geophysical studies around Okinawa Islands_-around Okinoerabu-jima Island_-preliminary reports on research in the 2012 fiscal year. GSJ Interim Report, No. 61. Geological Survey of Japan (AIST), Tukuba, pp 29-39. in Japanese

Seno T, Stein S, Gripp AE (1993) A model for the motion of the Philippine Sea Plate consistent with NUVEL-1 and geological data. J Geophys Res 98:17941-17948

Shinjo R (1999) Geochemistry of high Mg andesites and the tectonic evolution of the Okinawa Trough Ryukyu arc system. Chem Geol 157:69-88

Shinjo R, Ban M, Saito K, Kato Y (1991) K-Ar dating of the volcanic rocks in the Ryukyu arc. J Jpn Assoc Miner Petrol Econ Geol 86:323-328 (in Japanese with English abstract)

Shinjo R, Chung SL, Kato Y, Kimura M (1999) Geochemical and Sr-Nd isotopic characteristics of volcanic rocks from the Okinawa Trough and Ryukyu Arc: implications for the evolution of a young, intracontinental back arc basin. J Geophys Res 104:10591-10608

Shiono K, Mikumo T, Ishikawa Y (1980) Tectonics of the Kyushu-Ryukyu arc evidenced from seismicity and focal mechanisms of shallow to intermediate-depth earthquakes. J Phys Earth 28:17-43

Sibuet JC, Letouzey J, Barbier F, Charvet J, Foucher JP, Hilde TWC, Kimura M, Chiao LY, Marsset B, Muller C, Stephan JF (1987) Back arc extension in the Okinawa Trough. J Geophys Res 92:14041-+

Sibuet J-C, Hsu S-K, Shyu C-T, Liu C-S (1995) Structural and kinematic evolutions of the Okinawa Trough backarc basin. In: Taylor B (ed) Backarc basins. Springer, US, pp 343-379

Sibuet JC, Deffontaines B, Hsu SK, Thareau N, Le Formal JP, Liu CS, Party ACT (1998) Okinawa trough backarc basin: early tectonic and magmatic evolution. J Geophys Res 103:30245-30267

Tatsumi Y (1986) Formation of the volcanic front in subduction zones. Geophys Res Lett 13:717-720

Wessel P (2010) Tools for analyzing intersecting tracks: the x2sys package. Comput Geosci 36:348-354

Yokose H, Sato H, Fujimoto Y, Mirabueno MHT, Kobayashi T, Akimoto K, Yoshimura H, Morii Y, Yamawaki N, Ishii T, Honza E (2010) Mid-Pleistocene submarine acidic volcanism of the Tokara Islands, Japan. J Geogr (Chigaku Zasshi) 119(1):46-68 (in Japanese with English abstract)

\section{doi:10.1186/1880-5981-66-68}

Cite this article as: Sato et al:: Detailed bathymetry and magnetic anomaly in the Central Ryukyu Arc, Japan: implications for a westward shift of the volcanic front after approximately 2.1 Ma. Earth, Planets and Space 2014 66:68.

\section{Submit your manuscript to a SpringerOpen ${ }^{\odot}$ journal and benefit from:}

- Convenient online submission

- Rigorous peer review

- Immediate publication on acceptance

- Open access: articles freely available online

- High visibility within the field

- Retaining the copyright to your article

Submit your next manuscript at $>$ springeropen.com 